\title{
Pendidikan Perdamaian dengan 12 Nilai Dasar Perdamaian
}

\author{
I Putu Ayub Darmawan \\ Sekolah Tinggi Teologi Simpson \\ putuayub.simpson@gmail.com
}

\begin{abstract}
Conflict is a problem that is being faced in Indonesia. A peaceful way is needed to bring peace to a multicultural nation. From the analysis of various biblical literature and texts there are several peace values, including education for peace must guide students to accept themselves, peace education provides guidance to avoid bad prejudice, needs to be built understanding and attitudes that respect ethnic diversity, religious differences, different types sex, social status such as poor wealth, and group differences, in an effort to build a path for peace, students need to understand diversity, understand conflict, build an attitude of resisting violence, willingness to start admitting mistakes, and willingness to forgive.
\end{abstract}

Keywords: education; peace; basic values

\begin{abstract}
Abstrak: Konflik merupakan masalah yang sedang dihadapi di Indonesia. Perlu dilakukan cara damai untuk menghadirkan perdamaian di bangsa yang multikultural. Dari analisis berbagai literatur dan teks Alkitab ada beberapa nilai-nilai per-damaian, antara lain pendidikan untuk perdamaian harus membimbing murid menerima dirinya sendiri, pendidikan perdamaian memberikan bimbingan untuk mengindari prasangka buruk, perlu dibangun pengertian dan sikap yang menghargai keragaman etnis, perbedaan agama, perbedaan jenis kelamin, status sosial seperti kaya miskin, dan perbedaan kelompok, dalam upaya membangun jalan menunju perdamaian maka murid perlu memahami adanya keragaman, memahami konflik, membangun sikap menolak kekerasan, adanya kerelaan untuk memulai mengakui kesalahan, dan kerelaan untuk memberi maaf.
\end{abstract}

Kata Kunci: nilai-nilai dasar; pendidikan; perdamaian

Article History : $\quad$ Received: 16-03-2019 Revised: 10-04-2019 Accepted: 06-05-2019

\section{Pendahuluan}

Mencermati kehidupan sosial masyarakat di Indonesia, konflik terjadi di berbagai tempat. Konflik tersebut terjadi baik karena faktor kehidupan sosial, ideologi, politik, dan lain sebagainya. Dalam beberapa tahun terakhir, konflik terjadi karena faktor politik yang juga memanfaatkan isu agama. Di tengah situasi yang demikian, pendidikan perdamaian penting karena manusia hidup dalam dunia yang disertai kekerasan. Walau fenomena ini bukan fenomena baru melainkan fenomena yang sudah terjadi lama, komunitas gereja perlu memberi tempat untuk isu ini. Di era pasca-modernitas, penala- 
ran manusia tidak membuat fenomena konflik lenyap, konflik dengan kekerasan tampaknya menjadi semakin besar dan dampaknya juga sangat besar. Selain itu, Tirsa Budiarti mengungkapkan bahwa dalam konteks Indonesia, kekerasan awalnya terjadi dalam kehidupan rumah tangga, lembaga pendidikan, tempat kerja, kemudian terjadi juga dalam hidup bermasyarakat melalui konflik-konflik sosial. Tirsa Budiarti kemudian mencontohkan kasus kerusuhan yang terjadi di Ambon, Poso, Papua dan beberapa tempat lain. Menurut Budiarti, konflik dapat terjadi karena dilatarbelakangi oleh perbedaan suku, ras, kepentingan, kesenjangan ekonomi, kemudian terjadi pula konflik yang bernuansa agama yang berakhir dengan suatu tindakan kekerasan yang merenggut nyawa. $^{1}$

Pada dasarnya, perbedaan tersebut bukanlah akar masalahnya sebab perbedaan tersebut merupakan kekayaan sebagaimana dikemukakan oleh Nugroho bahwa masyarakat yang multikultural merupakan kekayaan bangsa. Walau demikian, Nugroho menyadari bahwa kekayaan tersebut sedang berhadapan dengan bahaya segregasi sosial di mana politik identitas mencuat. ${ }^{2}$ Kasus yang terjadi beberapa waktu lalu di berbagai daerah terjadi karena adanya faktor politik identitas yang dijadikan sebagai cara menyerang kelompok lawan. Sinaga mengemukakan bahwa konflik di Indonesia menjadi semakin nyata karena adanya kelompok-kelompok yang intoleran. Menurut Sinaga, sikap intoleran dapat menimbulkan bahaya bagi kehidupan berbangsa di Indonesia yang multikultural. ${ }^{3}$ Apabila konflik dibiarkan terus berkepanjangan maka dapat menimbulkan perpecahan bangsa Indonesia yang merupakan bangsa yang bersifat multikultural.

Konflik yang terjadi di Indonesia telah mengarah terjadinya kekerasan yang sistematis dan begitu kasat mata, serta kekerasan yang bernuansa agama adalah kekerasan yang paling mengerikan terjadi di negeri ini. ${ }^{4}$ Kekerasan yang terjadi di Indonesia, sebagaimana dikemukan oleh Mulia terjadi karena berbagai faktor. Salah satu faktor penyebabnya dikemukakan oleh Parsudi Suparlan. Dalam jurnalnya, Parsudi Suparlan menjelaskan faktor terjadinya konflik adalah karena adanya perjuangan individu atau kelompok untuk memenangkan suatu tujuan yang sama-sama ingin dicapai dan dalam konflik tujuannya adalah untuk menghancurkan pihak lain. ${ }^{5}$ Perjuangan individu maupun kelompok yang berlebih dapat mengabaikan hadirnya kelompok lain sebagai

\footnotetext{
${ }^{1}$ Tirsa Budiarti, “Model-Model Pendidikan Perdamaian Bagi Anak Dalam Konteks Gereja," Jurnal Jaffray 16, no. 1 (March 18, 2018): 55-76.

${ }^{2}$ Oktavianus Heri Prasetyo Nugroho, "Meretas Damai Di Tengah Keberagaman: Mengembangkan Pendidikan Kristiani Untuk Perdamaian Dalam Perspektif Multikulturalisme," Gema Teologi 38, no. 2 (2014): 143-170.

${ }^{3}$ Sahat M. Sinaga, "Negeri Pancasila: Panggilan Inklusif Gereja Di Indonesia," in Melaksanakan Amanat Agung Di Abad 21 (Ungaran: Sekolah Tinggi Teologi Simpson, 2017), 18.

${ }^{4}$ Musdah Mulia, "Melawan Kekerasan Atas Nama Agama," in Teologi Politik (Makassar: Yayasan Oase Intim, 2013), 165.

${ }^{5}$ Parsudi Suparlan, "Konflik Sosial Dan Alternatif Pemecahannya," Antropologi Indonesia 30, no. 2 (2006): 138-150.
} 
satu bagian penting dalam membangun bangsa. Jadi konflik merupakan masalah besar yang terjadi di Indonesia dan diperlukan cara damai untuk memecahkan masalah tersebut.

Karena terjadinya berbagai konflik, maka diperlukan pendidikan perdamaian sehingga dapat meminimalkan terjadinya konflik dalam berbagai bidang. Budiarti mengungkapkan bahwa pendidikan perdamaian diperlukan agar dapat menciptakan perdamaian positif dengan upaya memberi keterampilan untuk mencegah konflik dan kekerasan. ${ }^{6}$ Walau demikian, tetap harus disadari bahwa menghilangkan konflik sangat kecil kemungkinannya, tetapi meminimalkan konflik sangat mungkin dilakukan. Salah satu cara yang dapat ditempuh untuk meminimalkan konflik adalah dengan adanya pendidikan perdamaian.

Saputra dalam jurnalnya menuliskan:

UNICEF mendefinisikan pendidikan kedamaian sebagai proses mempromosikan pengetahuan, keterampilan, sikap dan nilai-nilai yang diperlukan untuk membawa perubahan perilaku yang akan memungkinkan anak-anak, remaja dan orang dewasa untuk (a) mencegah konflik dan kekerasan, baik terang-terangan dan struktural; (b) untuk menyelesaikan konflik secara damai; dan (c) untuk menciptakan kondisi yang kondusif bagi perdamaian, apakah pada intrapersonal, interpersonal, antarkelompok, tingkat nasional atau internasional. ${ }^{7}$

Sementara Vita dalam jurnalnya menjelaskan ada dua konsep damai yaitu damai negatif (negative peace) yang merujuk pada ketiadaan perang atau kekerasan fisik dan damai positif (positive peace) yang merujuk kepada adanya keadilan dan hubungan yang tidak eksploitatif, maupun kesejahteraan manusia dan lingkungan, demikian juga berkurangnya akar penyebab konflik. ${ }^{8}$ Kemudian Nugroho menekankan bahwa konsep perdamaian adalah perdamaian yang bersifat dinamis, progresif (ke masa depan), dan transformatif (ada perubahan), serta diperoleh dengan upaya sengaja secara intensional, termasuk melalui pendidikan yang mendorong atau merangsang potensi-potensi perdamaian dan tidak justru mengembangkan eksklusivitas dan triumphalisme dangkal. ${ }^{9}$

Dari beberapa pengertian di atas, pendidikan perdamaian merupakan sebuah proses yang bersifat dinamis, progresif, dan transformatif, serta diperoleh dengan upaya sengaja secara intensional untuk mempromosikan pengetahuan, keterampilan, sikap dan nilai-nilai yang diperlukan untuk membawa perubahan perilaku, hingga akhirnya dapat mewujudkan terjadinya kesejahteraan manusia dan lingkungan, dan akhirnya mampu meminimalkan akar penyebab konflik. Pendidikan perdamaian merupakan se-

\footnotetext{
${ }^{6}$ Budiarti, “Model-Model Pendidikan Perdamaian Bagi Anak Dalam Konteks Gereja," 58.

${ }^{7}$ Wahyu Nanda Eka Saputra, "Pendidikan Kedamaian: Peluang Penerapan Pada Pendidikan Tingkat Dasar Di Indonesia," Jurnal CARE (Children Advisory Research and Education) 3, no. 3 (March 16, 2016): 88-94.

${ }^{8}$ Yan Vita, "Penamanan Budaya Damai Via Pendidikan," Dimas: Jurnal Pemikiran Agama untuk Pemberdayaan 14, no. 1 (March 7, 2016): 17-28.

"Nugroho, "MERETAS DAMAI DI TENGAH KEBERAGAMAN."
} 
buah usaha yang kompleks karena mengandung berbagai tujuan yaitu untuk menumbuhkan komitmen, menanamkan rasa cinta akan hadirnya kedamaian, hingga pada akhirnya memampukan peserta didiknya melakukan analisis kritis dan menyelesaikan konflik dengan cara damai hingga mereka layak disebut sebagai agen perdamaian. ${ }^{10}$ Kompleksitas pendidikan perdamaian terjadi karena pendidikan perdamaian dilaksanakan tidak hanya mencakup hal-hal kognitif melainkan pula aspek afektif, dan psikomotorik. Dengan demikian pendidikan perdamaian tidak hanya pada tatanan teoritis melainkan pula mencapai pada praktiknya.

Untuk mewujudkan pendidikan perdamaian, ada berbagai usaha dilakukan baik oleh pemerintah, kelompok masyarakat, dan individual. Dalam usaha mewujudkan perdamaian, ada sebuah usaha Erik Lincoln dan Irfan AmaLee menyusun modul pendidikan perdamaian. Modul tersebut mengemukakan ada dua belas nilai dasar perdamaian yang digunakan sebagai materi dalam kegiatan Peace Generation. Dalam laman websitenya, Irvan AmaLee menjelaskan bahwa Peace Generation di Indonesia bermulai dari pertemuan antara Irfan AmaLee dan Eric Lincoln pada tahun 2006 di sebuah kelas Bahasa Inggris, di mana Irfan AmaLee menjadi salah satu murid dari Eric Lincoln di kantor penerbit Mizan. Dalam sesi conversation, Eric Lincoln mengajukan pertanyaan kepada siswa tema tentang perpolitikan dunia dan Irfan AmaLee mengemukakan pendapatnya, termasuk masalah konflik. Rupanya Eric Lincoln dan Irfan AmaLee sama-sama memilki ketertarikan pada pendidikan perdamain untuk anak dan remaja. Itu sebabnya sejak mereka bekerja sama menulis buku modul pendidikan perdamaian interaktif pertama di Indonesia. Modul tersebut, sejak diterbitkan telah diterapkan oleh berbagai organisasi lokal, nasional, mapun interansional seperti UNICEF, World Vision, UNESCO, dll. ${ }^{11}$ Penggunaan modul tersebut oleh UNESCO dan UNICEF tidak lepas dari semangat dua lembaga tersebut yang gencar melaksanakan usaha terjadinya pendidikan perdamaian, sebab pendidikan perdamaian memiliki potensi untuk menciptakan suatu budaya damai yang akan menjadi budaya tandingan bagi budaya kekerasan. ${ }^{12}$

Rumusan masalah penelitian ini adalah bagaimana pendidikan untuk perdamaian dengan dua belas nilai dasar perdamaian? Penelitian ini bertujuan untuk memaparkan tentang pendidikan untuk perdamaian dengan dua belas nilai dasar perdamaian.

\section{Metode Penelitian}

Penelitian ini adalah penelitian kualitatif studi literatur. Penulis merumuskan pendidikan Kristen untuk perdamaian dengan menggunakan nilai-nilai perdamaian yang dikembangkan oleh Erik Lincoln dan Irfan Amalee. Dalam bukunya, Erik Lincoln dan Irfan Amalee mengemukakan dua belas nilai dasar perdamaian dan merupakan buku

\footnotetext{
${ }^{10}$ Budiarti, "Model-Model Pendidikan Perdamaian Bagi Anak Dalam Konteks Gereja."

${ }^{11}$ Irfan AmaLee, "Sejarah Berdirinya PeaceGen," accessed June 15, 2018, http://irfanamalee.wixsite.com/pgproject/about1.

${ }^{12}$ Budiarti, “Model-Model Pendidikan Perdamaian Bagi Anak Dalam Konteks Gereja."
} 
panduan untuk pendidikan perdamaian, serta menjadi materi ajar peace generation. Buku panduan tersebut dilengkapi dengan dua belas buku siswa yang menolong siswa untuk mempelajari setiap nilai perdamaian. Secara umum dua belas nilai dasar tersebut dikelompokkan dalam tiga bagian yaitu berdamai dengan diri, hambatan menuju perdamaian, dan jalan menuju perdamaian. ${ }^{13}$

Dua belas nilai dasar perdamaian yang dikemukakan oleh Erik Lincoln dan Irfan Amalee kemudian dielaboarsi dengan berbagai sumber literatur yang relevan, sehingga nilai-nilai yang dikemukakan dapat digunakan dalam pendidikan Kristen untuk perdamaian. Hasil penelitian ini kemudian direview oleh Erik Lincoln sebagai penggagas buku nilai-nilai dasar perdamaian dan beberapa reviewer yang relevan lainnya. Masukan yang diberikan oleh Erik Lincoln dan beberapa reviewer digunakan untuk sebagai masukan untuk perbaikan dalam pembahasan penelitian ini.

\section{Hasil dan Pembahasan}

Berdasarkan analisis terhadap karya Lincoln dan AmaLee serta berbagai bahan pustaka maupun Alkitab maka ada dua belas nilai perdamaian yang menjadi dasar pendidikan perdamaian. Dua belas nilai perdamaian tersebut dikelompokkan dalam tiga kelompok utama.

\section{Membangun Perdamaian dari Diri Sendiri}

Bila mengacu pada nilai-nilai perdamaian yang dikemuakan oleh Lincoln dan AmaLee maka ada dua nilai dasar yang dikemukakan terkait berdamai dengan diri sendiri. Dua nilai dasar tersebut adalah menerima diri dan perbedaan etnis.

\section{Menerima Diri}

Lincoln dan AmaLee mengemukakan ada lima inti dasar dari prinsip ini. Inti pertama adalah "Setiap orang diciptakan dengan beberapa karakteristik" baik yang positif maupun negatif, serta yang bisa diubah dan tidak bisa diubah. Kedua, setiap orang harus bisa mengubah hal-hal yang bisa diubah, dan belajar menerima hal-hal yang tidak bisa diubah. Ketiga, setiap orang harus mensyukuri kebenaran bahwa dirinya diciptakan oleh Allah yang Mahakuasa dengan suatu tujuan dan Allah tidak pernah salah dalam menciptakan apapun. Keempat, manusia harus memiliki pandangan yang adil dan seimbang tentang diri sendiri. Kelima, tidak memandang rendah diri sehingga tidak mempersulit diri untuk memperoleh banyak teman. ${ }^{14}$ Nilai yang dikemukakan oleh Lincoln dan AmaLee dapat menjadi prinsip universal sehingga dapat diterima oleh banyak orang. Bagi pendidikan Kristen, nilai ini perlu diberi penekanan bahwa untuk berdamai dengan orang lain, manusia perlu terlebih dahulu berdamai dengan dirinya

\footnotetext{
${ }^{13}$ Erik Lincoln and Irfan AmaLee, Peace Generation: 12 Nilai Dasar Perdamaian (Bandung: Pelangi Mizan, 2007), v.

${ }^{14}$ Ibid, 4-5.
} 
sendiri. Untuk berdamai dengan diri sendiri, maka manusia haruslah terlebih dahulu diperdamaikan dengan Allah.

Peristiwa jatuhnya manusia dalam dosa dan menyebabkan manusia diusir dari Taman Eden merupakan sebuah "konflik" yang terjadi antara manusia dengan Allah. Dalam peristiwa tersebut, manusia melawan perintah Allah (Kej. 3). Oleh karena itu Allah mengutus Yesus Kristus menjadi pendamaian bagi manusia (II Kor. 5:19; Kol. 1:20; I Yoh. $2: 2 ; 4: 10$ ). Paulus menyebutkan bahwa berita pendamaian dalam Kristus telah dipercayakan kepadanya untuk terus diberitakan kepada semua orang (II Kor. 5:19). Sidjabat menjelaskan bahwa untuk berdamai dengan diri sendiri serta berdamai dengan semua orang maka manusia harus terlebih dahulu diperdamaikan dengan Allah melalui Kristus, sebab kasih Allah dalam Kristus Yesus dapat memampukan manusia untuk menjadi pembawa damai. ${ }^{15}$

Dalam pendidikan Kristen, pendidik perlu membimbing murid-muridnya untuk berdamai dengan diri sendiri (menerima diri sendiri). Sebagaimana dikemukakan di atas, pertama-tama yang harus dilakukan adalah menyadarkan murid bahwa dirinya berdosa dan menerima pendamaian dari Allah. Pendidik kemudian membimbing muridnya untuk berdamai dengan dirinya sendiri dan menerima dirinya sendiri. Yesus menegaskan hukum Tuhan bahwa "kasihilah sesamamu manusia seperti dirimu sendiri" (Mat. 19:19). Jadi berdamai dengan diri sendiri menjadi standar minimal yang kemudian digunakan untuk berdamai dengan orang lain.

\section{Prasangka}

Dalam berbagai kasus yang terjadi, prasangka menjadi salah satu awal terjadinya konflik. Lincoln dan AmeLee menjelaskan bahwa prasangka berarti bahwa memutuskan atau menghukum seseorang sebelum tahu fakta sebenarnya. ${ }^{16}$ Inti dasar prinsip perdamaian terkait prasangka adalah setiap orang perlu belajar untuk melihat setiap orang sebagai individu. Jadi, setiap manusia tidak boleh dicap baik atau buruk, pintar atau bodoh, kaya atau miskin hanya berdasarkan kesukuan, agama, dan status sosialnya. Yang melandasi prinsip perdamaian ini adalah setiap orang memiliki hak untuk memiliki identitasnya sendiri, bukan karena golongannya. Harus diingat bahwa setiap manusia tidak dapat memilih lahir dalam keluarga apa, suku apa, maupun status sosial, itu berarti bahwa setiap manusia lahir dalam derajat yang sama.

Lincoln dan AmaLee memberi penegasan bahwa prasangka yang buruk menyebabkan dipersempitnya ruang lingkup pergaulan. Selain itu, prasangka buruk merupakan ciri kepicikan berpikir, sehingga terjebak dalam prasangkanya sendiri. ${ }^{17}$ Selain itu, dalam laman peace-generation.org dituliskan bahwa "Karena kekerasan

\footnotetext{
${ }^{15}$ Binsen S. Sidjabat, Mendidik Warga Gereja Melalui Seri Selamat (Jakarta: BPK Gunung Mulia, 2018), 310.

${ }^{16}$ Erik Lincoln and Irfan AmaLee, No Curiga, No Prasangka: Tentang Prasangka (Bandung: Pelangi Mizan, 2007), 3.

${ }^{17}$ Lincoln and AmaLee, Peace Generation: 12 Nilai Dasar Perdamaian, 20, 22-23.
} 
diawali dengan kondisi yang tidak saling memahami."18 Senada dengan itu, Juditha menjelaskan bahwa prasangka muncul dari kondisi yang tidak saling kenal, tetapi Juditha mengemukakan bahwa prasangka juga muncul karena adanya kekhawatiran yang berwujud stereotif, kesenjangan sosial, serta adanya sikap diskriminasi terhadap suku lain. ${ }^{19}$ Itu berarti situasi yang tidak saling kenal dapat menyebabkan adanya prasangka yang kemudian menimbulkan terjadinya kekerasan.

Dalam pendidikan Kristen, pendidikan untuk perdamaian perlu diberikan dengan memberi penekanan pada meminimalkan prasangka buruk terhadap orang lain. Prinsip Alkitab yang melandasi hal ini adalah Yakobus 2:1-13. Dalam teks tersebut dituliskan bahwa setiap orang yang yang beriman kepada Yesus Kristus, jangan menunjukkan iman dengan memandang muka. Dalam teks Yakobus 2:1-13 ditekankan agar tidak membangun prasangka dengan melihat penampilan orang lain. Yakobus meyajikan perbandingan antara orang kaya yang memakai cincin emas dan pakaian indah dan orang miskin yang memakai pakaian buruk, dan kemudian orang percaya menunjukkan prasangkanya dengan menghormati orang yang berpakaian indah. Prinsip teologis yang ditekankan dalam teks Yakobus 2:1-13 adalah "Allah memilih orang-orang yang dianggap miskin oleh dunia ini untuk menjadi kaya dalam iman dan menjadi ahli waris Kerajaan yang telah dijanjikan-Nya kepada barangsiapa yang mengasihi Dia." Yakobus kemudian menekankan bahwa membangun prasangka buruk dengan memandang muka, merupakan perbuatan dosa. Kemudian ditekankan bahwa penghakiman yang tak berbelas kasihan berlaku atas orang yang tidak berbelas kasihan, semntara belas kasihan akan menang atas penghakiman (Yak. 2:13).

Bagi pendidik Kristen, nilai ini perlu menjadi penekanan dalam setiap pembelajaran. Pendidik perlu menolong murid untuk memiliki prasangka yang baik. Terciptanya prasangka yang baik bermula dari penerimaan diri sendiri dengan baik juga. Oleh sebab itu, nilai ini menjadi bagian lanjutan dari nilai pertama.

\section{Meminimalkan Hambatan Menuju Perdamaian}

Nilai-nilai dalam bagian ini terkait dengan dua nilai yang telah dikemukakan sebelumnya.

\section{Keragaman Etnis}

Perbedaan etnis merupakan isu indetitas yang terjadi pada masa kini. Dalam beberapa kasus, perbedaan warna kulit, bentuk mata, maupun rambut menjadi masalah yang menimbulkan kesenjangan antar kelompok. Kelompok yang satu merasa lebih unggul dari kelompok lainnya. Lincoln dan AmeLee dalam bukunya mengemukakan bahwa prinsip penting dalam perdamaian adalah menghindari kecenderungan berprasangka

\footnotetext{
${ }^{18 “ C e r i t a ~ K a m i, " ~ a c c e s s e d ~ J u n e ~ 15, ~ 2018, ~ h t t p: / / w w w . p e a c e-g e n e r a t i o n . o r g / a b o u t . ~}$

${ }^{19}$ Christiany Juditha and Christiany Juditha, "Stereotip dan Prasangka dalam Konfl ik Etnis Tionghoa dan Bugis Makassar," Jurnal ILMU KOMUNIKASI 12, no. 1 (June 17, 2015): 87-104.
} 
buruk terhadap suku-suku lain dan berusaha untuk mengenali serta menikmati perbedaan..$^{20}$ Nilai ini dalam perspektif dikemukakan pula oleh Zainiyati. Zainiyati yang menjelaskan bahwa dengan membangun pemahaman yang baik akan orang lain dan adanya keberagaman maka nilai-nilai universal yang ada dalam agama sepeti kebenaran, keadilan, kemanusiaaan, perdamaian dan kesejahteraan umat manusia dapat ditegakkan. $^{21}$

Demikian halnya dalam Alkitab, Alkitab sendiri menunjukkan bahwa Allah terlibat dalam terciptanya keduabelas suku Israel. Sementara Yesus Kristus sendiri menunjukkan bahwa perbedaan suku tidak menjadi masalah dalam membangun hubungan. Yesus Kristus mencontohkan bagaimana Ia datang meminta minum kepada seorang perempuan Samaria (Yoh. 4:1-42). Bahkan dalam cerita Yohanes 4:1-42, Yesus Kristus tidak hanya meminta minum, Ia berbicara dengan perempuan Samaria dan menyampaikan syalom bagi perempuan tersebut. Oleh karena itu, dalam pendidikan Kristen perlu ditekankan adanya kepelbagaian suku dan sikap saling menghargai serta saling menerima sebagai sama-sama ciptaan Allah.

Lincoln dan AmeLee mengemukakan ada lima hal penting terkait perbedaan suku, yaitu: Pertama, perbedaan suku bukan untuk saling memerangi, melainkan untuk saling memahami; Kedua, setiap suku memiliki keunikannya masing-masing, yang mana dalam setiap adat dan kebudayaan, terdapat hal-hal yang baik maupun kurang baik atau memiliki kelebihan dan kekurangan masing-masing; Ketiga, semua manusia pada dasarnya diciptakan sama di hadapan Allah. Allah tidak menciptakan manusia yang satu paling baik dan yang lainnya kurang baik, oleh karena itu tidak ada suku yang paling unggul atau kurang unggul; Keempat, prasangka yang buruk dan ketidaktahuan sering kali memperkeruh pikiran orang yang satu terhadap yang lainnya; Kelima, prasangka buruk dapat diatasi dengan menjalin hubungan silaturahmi dengan orang dari suku lain. ${ }^{22}$ Rumbi menjelaskan bahwa sikap mau menghargai merupakan kunci penting dalam menciptakan perdamaian. Sikap menghargai dapat meminimalkan adanya prasangka buruk yang dapat memicu konflik. ${ }^{23}$

\section{Perbedaan Agama}

Salah satu penyebab adanya konflik di Indonesia adalah masyarakat belum cukup mampu untuk menerima adanya perbedaan, termasuk juga terbedaan keagamaan. ${ }^{24}$ Dalam upaya menghadirkan perdamaian, perlu kesadaran akan keberagaman, termasuk beragam agama. Setiap orang tidak dapat dipaksakan untuk memeluk satu agama,

\footnotetext{
${ }^{20}$ Lincoln and AmaLee, Peace Generation: 12 Nilai Dasar Perdamaian, 34.

${ }^{21}$ Husniyatus Salamah Zainiyati, "Pendidikan Multikultural: Upaya Membangun Keberagamaan Inklusif di Sekolah," ISLAMICA: Jurnal Studi Keislaman 1, no. 2 (March 2, 2007): 135-145.

${ }^{22}$ Lincoln and AmaLee, Peace Generation: 12 Nilai Dasar Perdamaian, 36-36.

${ }^{23}$ Frans P. Rumbi, “Tradisi Massuru' dan Pertobatan Dalam Injil Sinoptik," BIA': Jurnal Teologi dan Pendidikan Kristen Kontekstual 1, no. 1 (June 30, 2018): 26-38.

${ }^{24}$ Sitti Mania, "Implementasi Pendidikan Multikultural Dalam Pembelajaran," Lentera Pendidikan : Jurnal Ilmu Tarbiyah dan Keguruan 13, no. 1 (June 22, 2010): 78-91.
} 
melainkan dengan kerelaan dirinya sendiri menganut satu agama. Prinsip universal yang ditekankan oleh Lincoln dan AmaLee adalah Pertama, tidak ada satu pun agama yang mengajarkan penganutnya untuk menjadi jahat; Kedua, ada banyak kemiripan dalam agama-agama; Ketiga, ada perbedaan mendasar yang diajarkan agama, misalnya tentang surga, kitab suci, termasuk tentang para nabi; Keempat, membuktikan kebenaran agama dalam praktik keseharian, berbicara keyakinan secara dialogis dan saling menghormati lebih baik daripada menghabiskan waktu dengan saling menjelekkan, menindas, dan melawan satu sama lain; Kelima, tidak boleh menggunakan kekerasan untuk memaksa seseorang menganut dan melawan satu sama lain. ${ }^{25}$

Dalam kekristenan, konflik bernuansa agama menjadi salah satu latar yang mewarnai peristiwa salib. Pemimpin agama Yahudi merasa terancam dengan kehadiran Yesus Kristus yang mendobrak kebiasaan munafik pemimpin agama pada masa itu. Itu sebabnya, isu agama dimunculkan menjadi salah satu tuduhan terhadap Yesus. Tetapi menurut Rumbi, kekristenan mula-mula memberikan penekanan bahwa pertobatan yang terjadi pada orang Kristen mula-mula menghasilkan sikap yang berbela rasa sehingga menghindarkan tindakan diskriminatif. ${ }^{26}$ Dalam menggunakan nilai ini, para pendidik Kristen perlu memberikan penekanan dalam pengajarannya bahwa perbedaan agama tidak perlu disikapi dengan sikap yang diskriminatif, sehingga terbangun sikap belarasa dan tidak diskriminatif pada para murid. Perbedaan agama perlu disikapi dengan menunjukkan kasih Kristus yang menjadi bagian dari perilaku hidup orang Kristen. Perilaku tersebut tentunya sebuah wujud dari ekspresi iman pada Kristus yang mengasihi manusia.

\section{Perbedaan Jenis Kelamin}

Ada dua prinsip penting dalam nilai perdamaian ini, yaitu: Pertama, laki-laki dan perempuan diciptakan oleh Allah secara sepadan, jadi mereka harus saling memperlakukan dengan adil; Kedua, hormati dan hargai hak-hak orang yang berbeda jenis kelamin, bagi laki-laki tidak melakukan pelecehan, diskriminasi, dan intimidasi dengan menggunakan fisik maupun lisan, sementara bagi perempuan tidak mempermainkan laki-laki, membeda-bedakan teman baik terhadap laki-laki maupun perempuan, dan menyakiti dengan kata-kata. ${ }^{27}$ Terkait dengan perbedaan jenis kelamin, Verkuyl membahas mengenai keterangan Alkitab mengenai perbedaan jenis kelamin. Verkuyl menjelaskan bahwa Tuhan menciptakan laki-laki dan perempuan menurut gambar dan rupa-Nya (Kej. 1) dan kedua manusia tersebut diciptakan berbeda jenis

\footnotetext{
${ }^{25}$ Lincoln and AmaLee, Peace Generation: 12 Nilai Dasar Perdamaian, 54-55.

${ }^{26}$ Rumbi, "Tradisi Massuru' dan Pertobatan Dalam Injil Sinoptik."

${ }^{27}$ Lincoln and AmaLee, Peace Generation: 12 Nilai Dasar Perdamaian, 68-70.
} 
kelamin, supaya kedua jenis kelamin tersebut saling melengkapi, saling menolong dan saling melayani. ${ }^{28}$

Diskriminasi gender dapat menjadi penyebab berbagai masalah, dengan melihat prinsip Alkitab dalam Kejadian 1 dan nilai-nilai perdamaian dalam dua belas nilai perdamaian yang dikemukakan oleh Lincoln dan Amalee maka pendidikan Kristen harus menanamkan nilai bahwa laki-laki maupun perempuan adalah ciptaan Allah dan dipandang dalam kedudukan yang sama. Walau demikian keduanya memiliki peran masing-masing sebagai bagian dari perbedaan yang Allah berikan.

\section{Kaya dan Miskin}

Kata kunci untuk nilai ini adalah kekayaan maupun kemiskinan tidak menentukan nilai seseorang, sehingga setiap orang harus diperlakukan dengan rasa hormat. ${ }^{29}$ Brownlee menjelaskan bahwa dalam prinsip Alkitab, setiap manusia dianggap penting. Allah menciptakan manusia dalam gambar Allah. Rambut setiap orang la perhatikan (Mat. 10:30), kemudian Ia menunjukkan kasih-Nya pada manusia dengan menyamakan diriNya dengan gembala. ${ }^{30}$ Penjelasan Brownlee menunjukkan bahwa Yesus Kristus memberi teladan bagaimana menghargai manusia. Ia tidak memandang rendah orang lain karena strata sosial, kaya atau miskin. Walau manusia berdosa, Ia menaruh belas kasihan kepada manusia.

Terkait dengan pendidikan atau penanaman nilai ini, Lincoln dan AmaLee mengungkapkan tiga hal yang penting terkait kaya dan miskin, yaitu: Pertama, jangan menghargai atau tidak menghargai seseorang berdasarkan dengan apa yang mereka miliki, sebab hidup orang tidak bergantung pada hartanya; Kedua, orang kaya maupun miskin sama-sama menghadapi godaan seperti kesombongan, menindas, keserakahan, kurang bergantung pada Tuhan, iri hati, dan suka mengkritik; Ketiga, belajar bergaul dengan orang dari semua tingkat ekonomi, sehingga dapat belajar satu dengan yang lain. ${ }^{31}$ Dalam penelitiannya, Rumbi menjelaskan bahwa sikap membeda-bedakan, baik strata sosial, kondisi ekomoni dan berbagai perbedaan lainnya dapat memicu terjadinya konflik. $^{32}$ Itu sebabnya pendidikan perdamaian perlu menekankan menghargai orang lain yang memiliki perbedaan strata sosial maupun kondisi ekonomi.

Dalam berbagai peristiwa Yesus menerobos sekat pemisah yang dibangun untuk membedakan antara kaya atau miskin. Yesus menunjukkan bagaimana Ia hadir di rumah Zakheus (Luk. 19:1-10), kemudian dalam khotbah di bukit Yesus Kristus justru menampilkan orang miskin dalam ucapan bahagia (Mat. 5:1-12; Luk. 6:20-23). Dalam

\footnotetext{
${ }^{28}$ J. Verkuyl, Etika Kristen: Seksuil (Jakarta: BPK Gunung Mulia, 1989), 15.

${ }^{29}$ Lincoln and AmaLee, Peace Generation: 12 Nilai Dasar Perdamaian, 82.

${ }^{30}$ Malcolm Brownlee, Tugas Manusia Dalam Dunia Milik Tuhan (Jakarta: BPK Gunung Mulia, 2004), 19.

${ }^{31}$ Lincoln and AmaLee, Peace Generation: 12 Nilai Dasar Perdamaian, 87-89.

${ }^{32}$ Frans Paillin Rumbi, “Manajemen Konflik Dalam Gereja Mula-Mula: Tafsir Kisah Para Rasul 2:4147," Evangelikal: Jurnal Teologi Injili dan Pembinaan Warga Jemaat 3, no. 1 (January 30, 2019): 9-20.
} 
Matius 11:5 juga ditunjukkan bahwa orang-orang miskin memperoleh perhatian dalam pelayanan Yesus. Dari beberapa teks Alkitab jelas jika Yesus Kristus tidak memandang rendah orang miskin. Ia justru beberapa kali membela kaum miskin yang tertindas oleh sistem keagamaan, sosial, dan politik yang dibangun manusia pada waktu itu.

Oleh sebab itu, dalam upaya membangun perdamaian sikap membedakan kaya dan miskin harus dihindarkan. Sikap demikian merupakan perwujudan dari adanya dosa dalam diri manusia, di mana dosa menyebabkan manusia tidak menghargai karya Allah termasuk manusia yang lainnya. Pendidikan Kristen perlu menanamkan nilai bahwa kaya dan miskin sama di mata Allah, tidak ada yang kaya menganggap diri lebih tinggi dan dapat menindas yang miskin karena dianggap lemah.

\section{Perbedaan Kelompok}

Eksklusifitas kelompok merupakan salah satu sumber konflik. Oleh karena itu, dalam membangun perdamaian, perlu menyadari bahwa kelompok eksklusif dapat menyakiti sahabat dan dapat menimbulkan banyak kerugian. Kelompok eksklusif dapat menyebabkan timbulnya batasan yang sempit, tidak harmonisnya hubungan satu dengan yang lain, terjadinya perselisihan yang menimbulkan kerugian. ${ }^{33}$ Pergaulan dalam kelompok eksklusif mendorong seseorang untuk menyisihkan orang lain yang mungkin berbeda suku, agama, bahasa, dan ras.

Dalam 1 Korintus 1:11-16, Paulus mengungkapkan adanya perselisihan di antara jemaat Korintus yang terpecah dalam beberapa kelompok. Dari teks 1 Korintus 1:11-16, tampaknya ada yang menyebut diri mereka dari golongan Paulus, atau dari golongan Apolos, golongan Kefas, maupun dari golongan Kristus. Ekslusifitas kelompok dalam menjadi masalah bagi kemajuan sebuah komunitas, itu sebabnya Paulus mencoba menyelesaikan hal itu dengan mengirim surat kepada jemaat Korintus.

Bagi pendidikan Kristen, nilai perbedaan kelompok perlu menjadi materi yang diajarkan. Jika mencermati penciptaan manusia, tampak jelas jika Allah menciptakan manusia berbeda, laki-laki dan perempuan. Kedua kelompok gender tersebut Allah pandang baik. Demikian pula pada bangsa Israel, Allah membagi bangsa Israel dalam dua belas suku. Allah juga mengatur mereka agar mereka dapat hidup berdampingan dan saling melengkapi. Itu sebabnya praktik pendidikan Kristen harus memberi pengertian pada murid pentingnya menghargai perbedaan kelompok. Dengan memberikan pendidikan yang menghargai perbedaan kelompok maka murid-murid dapat dibekali untuk hidup di negara yang multikultural.

\section{Membangun Jalan Menuju Perdamaian}

Untuk membangun jalan menuju perdamaian, Lincoln dan AmaLee mengemukakan lima jalan. Lima jalan tersebut sejalan dengan nilai-nilai kekristenan sehingga dapat diguna-

\footnotetext{
${ }^{33}$ Lincoln and AmaLee, Peace Generation: 12 Nilai Dasar Perdamaian, 98.
} 
kan untuk menghadapi kekerasan dan konflik. Lima jalan tersebut adalah bagian dari dua belas nilai perdamaian dan dapat digunakan pula dalam pendidikan Kristen untuk perdamaian.

\section{Memahami Keragaman}

Dari penelitian Sidjabat terhadap tulisan Ismail, tampak jelas jika pendidikan Kristen perlu menekankan adanya kesadaran akan keberagaman. Sikap toleransi terbagun karena adanya pendidikan kemajemukan yang membantu memahami adanya keberagaman. ${ }^{34}$ Demikian pula dalam dua belas nilai perdamaian yang dikemukakan oleh Lincoln dan AmaLee, salah satu nilai yang ditekankan adalah memahami keragaman. Lincoln dan AmaLee mengungkapkan bahwa Allah menciptakan beragam hal untuk menjadikan dunia ini lebih indah, oleh sebab itu perbedaan dijadikan untuk saling melengkapi. Untuk dapat bersatu, maka perlu kesadaran akan keragaman sehingga muncul komitmen untuk menghargai yang lain. Lincoln dan AmaLee memberi penegasan bahwa Allahlah yang menciptakan segala sesuatu berbeda agar terjadi saling mengenal satu dengan yang lain. ${ }^{35}$ Contoh nilai keragaman yang diangkat oleh Lincoln dan AmaLee adalah Indonesia yang Bhineka Tunggal Ika. Bhineka Tunggal Ika adalah budaya nasional yang diangkat dari nilai-nilai budaya di Indonesia. Suparlan menjelas-kan bahwa upaya perdamaian harus diangkat pula dari nilai kebudayaan sehingga dapat saling menerima nilai tersebut. ${ }^{36}$

Kehidupan yang beragam merupakan kehidupan yang diciptakan oleh Allah. Hal itu terbukti dari penciptaan laki-laki dan perempuan (Kej. 1:27) dan penetapan dua belas suku Israel (Kej. 49:1-28). Teks dalam Kejadian 1:27 dan 49:1-28 menunjukkan adanya keragaman. Apabila Allah menetapkan adanya keragaman, maka pada dasarnya keragaman tidak dapat dijadikan alasan untuk berkonflik. Allah memberikan keragaman agar manusia dapat saling menolong. Bagi pendidikan perdamaian, nilai penting ini perlu terus diajarkan di negara yang multikultural.

\section{Memahami Konflik}

Lincoln dan AmaLee menjelaskan bahwa konflik pasti akan muncul, hanya respon terhadap konflik menentukan akibatnya, entah akan menyebabkan hubungan menjadi rusak atau justru menjadikan semakin dewasa. ${ }^{37}$ Dalam Alkitab terdapat konflik di Korintus. Menghadapi masalah yang terjadi di Korintus, Paulus tampaknya memulai dengan memahami konflik. Dengan memahami konflik yang terjadi di jemaat Korintus, Paulus kemudian dapat menuliskan sebuah surat yang memberikan pengajaran dan pemecahan

\footnotetext{
${ }^{34}$ Binsen Samuel Sidjabat, "Penguatan Guru PAK Untuk Pendidikan Karakter: Melihat Kontribusi Seri Selamat," Evangelikal: Jurnal Teologi Injili dan Pembinaan Warga Jemaat 3, no. 1 (January 30, 2019): 3048.

${ }^{35}$ Lincoln and AmaLee, Peace Generation: 12 Nilai Dasar Perdamaian, 116-117.

${ }^{36}$ Suparlan, "Konflik Sosial Dan Alternatif Pemecahannya," 149.

${ }^{37}$ Erik Lincoln and Irfan AmaLee, Konflik Bikin Kamu Makin Dewasa: Tentang Konflik (Bandung: Pelangi Mizan, 2007), i.
} 
masalah. Pendidikan perdamaian juga perlu memasukkan dalam materi maupun kurikulumnya bagaimana memahami konflik.

Lincoln dan AmaLee kemudian mengemukakan ada empat inti pelajaran dari nilai memahami konflik, yaitu: Pertama, harus disadari bahwa konflik pasti akan terjadi dan setiap orang pasti mengalaminya; Kedua, konflik adalah kesempatan untuk menjadi lebih dewasa, sehingga perlu kecerdasan untuk menyelesaikannya agar hubungan tidak menjadi rusak; Ketiga, bagaimana meresponi konflik menentukan akibatnya, apakah akan menyebabkan semakin terjerumus dalam konflik atau justru mengambil jalan damai; Keempat, konflik merupakan situasi yang dapat menjerumuskan pada tindakan ekstrem yang tidak sehat. Lincoln dan AmaLee mendorong agar menggunakan jalan damai untuk menyelesaikan konflik. Adapun langkah yang harus dilakukan adalah memutuskan untuk memaafkan dan menjauhi konflik, berbicara langsung dengan orang yang berselisih, dan meminta bantuan orang ketiga jika sulit ditangani dengan bicara empat mata. ${ }^{38}$

\section{Menolak Kekerasan}

Nilai perdamaian kesepuluh yang dikemukakan oleh Lincoln dan AmaLee adalah menolak kekerasan. Dalam buku Pakai Otak, Jangan Maen Otot, Lincoln dan AmaLee mengemukakan bahwa konflik menyebabkan menjadi semakin buruknya pelayanan kesehatan dan pendidikan, hancurnya berbagai infrastruktur, serta hambatan ekonomi, lebih dari itu, konflik menimbulkan menurunnya kepercayaan dan meningkatnya rasa saling curiga. ${ }^{39}$ Alasan penting perlunya membangun nilai menolak kekerasan karena kekerasan menghasilkan tiga dampak buruk, yaitu: Pertama, kekacauan. Kekerasan menyebabkan timbulnya lebih banyak kekerasan lagi dan situasi menjadi tidak terkendali, yang pada akhirnya menimbulkan kerusakan dan kesakitan; Kedua, kehilangan kesempatan untuk berdamai menyebabkan masalah dapat menjadi semakin besar dan semakin parah; Ketiga, perasaan tidak baik pada orang yang terjebak dalam kekerasan akan dipenuhi dengan perasaan takut, bersalah, dan dendam. Lebih jelas Lincoln dan AmaLee mengungkapkan bahwa bila menyelesaikan masalah dengan kekerasan, sama saja mencoba memadamkan api dengan minyak tanah. ${ }^{40}$

Dalam pengajaran Tuhan Yesus di bukit, Ia mengajarkan agar "Janganlah kamu melawan orang yang berbuat jahat kepadamu, melainkan siapapun yang menampar pipi kananmu, berilah juga kepadanya pipi kirimu" (Mat. 5:39). Kaidah hidup tersebut merupakan fondasi dari nilai menolak kekerasan. Tindakan kekerasan yang dibalas dengan kekerasan hanya akan menghasilkan konflik yang berkelanjutan. Tampaknya Yesus ingin agar murid-murid-Nya menolak kekerasan dengan menyatakan kasih. Bagi

\footnotetext{
${ }^{38}$ Lincoln and AmaLee, Peace Generation: 12 Nilai Dasar Perdamaian, 132, 149.

${ }^{39}$ Erik Lincoln and Irfan AmaLee, Pake Otak, Jangan Maen Otot: Tentang Menolak Kekerasan (Bandung: Pelangi Mizan, 2007), 1.

${ }^{40}$ Lincoln and AmaLee, Peace Generation: 12 Nilai Dasar Perdamaian, 151, 156.
} 
pendidikan Kristen, nilai ini adalah nilai perdamaian yang harus diajarkan kepada anakanak. Melalui pengajaran dan teladan, guru dapat menunjukkan sikap mengasihi sebagai bentuk menolak tindakan kekerasan.

\section{Mengakui Kesalahan}

Lincoln dan AmaLee menjelaskan bahwa konflik tidak akan terselesaikan jika tidak ada pihak yang mau mengakui kesalahan dan meminta maaf. ${ }^{41}$ Dalam bukunya yang lain, Lincoln dan AmaLee menegaskan bahwa dalam membangun perdamaian, mengakui kesalahan adalah permulaan dari penyelesaian masalah. Kemudian dijelaskan pula oleh Lincoln dan AmaLee bahwa sangat sulit untuk menyelesaikan sebuah konflik, sebab pilihan penyelesaiannya justru dapat mendorong munculnya kemarahan yang kemudian berdampak pada timbulnya usaha balas dendam dan akhirnya konflik menjadi semakin parah. Prinsip penting dari nilai ini adalah untuk menyelesaikan sebuah konflik, maka terlebih dahulu harus ada kesadaran untuk melihat kesalahan diri sendiri. Lincoln dan AmaLee menegaskan bahwa tidak ada konflik yang terjadi secara sepihak, melainkan melibatkan lebih dari satu pihak dan hampir setiap jalan keluar bermula ketika salah satu pihak mau mengakui kesalahannya dan meminta maaf. ${ }^{42}$ Konflik tidak akan selesai ketika semua pihak menunggu pihak yang lain untuk meminta maaf. Meminta maaf bukanlah perkara yang mudah untuk dilakukan, tetapi setiap manusia dapat melakukannya dengan pertolongan Allah yang Mahakuasa untuk melakukannya. ${ }^{43}$

Secara teologis, manusia adalah ciptaan yang terbatas, dan rusak karena dosa sehingga manusia tidak lepas dari kesalahan. Pemahanan ini perlu ditanamkan pada setiap orang Kristen untuk dapat menghargai orang lain dan mengakui kesalahan. Manusia tidak luput dari kesalahan, tetapi sebagai orang Kristen yang bertumbuh orang Kristen perlu menyadari kesalahan dan berbenah diri. Mengakui kesalahan dalam konteks pendidikan perdamaian merupakan sebuah cara untuk berbenah diri dan tidak mencari kesalahan orang lain. Dalam kurikulum pendidikan perdamaian, nilai ini perlu dibangun dalam diri para murid sehingga sikap berbenah diri dan tidak menyalahkan orang lain dapat terbangun.

\section{Memberi Maaf}

Pada nilai sebelumnya dikemukakan bahwa meminta maaf penting dalam upaya terjadinya perdamaian. Selanjutnya, memberi maaf juga merupakan nilai penting dalam terjadinya perdamaian. Lincoln dan AmaLee menyebutkan bahwa "Memaafkan adalah keputusan dan pembuka jalan untuk perdamaian." ${ }^{44}$ Senada dengan apa yang dikemukakan oleh Lincoln dan AmaLee, Christianto dalam penelitiannya menemukan bahwa memaaf-

\footnotetext{
${ }^{41}$ Erik Lincoln and Irfan AmaLee, Nggak Gengsi Ngaku Salah: Tentang Mengaku Kesalahan (Bandung: Pelangi Mizan, 2007), 3.

${ }^{42}$ Lincoln and AmaLee, Peace Generation: 12 Nilai Dasar Perdamaian, 162, 165.

${ }^{43}$ Lincoln and AmaLee, Nggak Gengsi Ngaku Salah: Tentang Mengaku Kesalahan, 4.

${ }^{44}$ Lincoln and AmaLee, Peace Generation: 12 Nilai Dasar Perdamaian, 178.
} 
kan merupakan bagian penting dalam menyelesaikan konflik maupun meminimalkan kembali terjadinya konflik. ${ }^{45}$ Ada empat prinsip penting dalam nilai perdamaian ini, yaitu: Pertama, memaafkan tidak harus menunggu merasa enak hati, sebab bila memaafkan dilakukan pada saat diri kecewa akan lebih mulia dibadingkan dalam keadaan biasa; Kedua, memberi maaf berarti memperbaiki kenyataan, bukan menimbun atau menghindari kenyataan. Dengan demikian memaafkan tidak berarti langsung melupakan kesalahan orang lain; Ketiga, memaafkan tidak berarti bahwa tidak ada masalah atau menganggap kesalahan dengan tidak ada masalah. Memaafkan merupakan langkah awal untuk menyelesaikan masalah dan meringankan beban perasaan; Keempat, memaafkan tidak memiliki batas waktu dan tempat, dan memaafkan merupakan cara untuk mencegah terjadinya masalah yang baru. ${ }^{46}$

Nilai memaafkan atau mengampuni merupakan nilai yang Tuhan Yesus ajarkan. Tuhan Yesus mengajarkan agar mengampuni orang yang bersalah (Mat. 6:12; Mrk. 11:25; Luk. 17:3). Dalam peristiwa penyaliban, Tuhan Yesus berkata "Ya Bapa, ampunilah mereka, sebab mereka tidak tahu apa yang mereka perbuat." (Luk. 23:34). Dalam peristiwa penyaliban Tuhan Yesus ada konflik antara manusia dengan Tuhan Yesus, tetapi justru Yesus mengatakan sebuah kalimat pengampunan.

Bagi praktik pendidikan Kristen, murid-murid juga harus diajarkan nilai memaafkan. Jika mencermati permasalahan yang terjadi di Indonesia maka setiap murid Kristus diharapkan untuk terus tampil memberi kesaksian yang baik. Salah satu nilai yang dapat menjadi kesaksian yang baik adalah memaafkan. Inti dari nilai memaafkan adalah kasih terhadap sesama manusia (Mat. 5:43-44; Mrk. 12:31). Inti kekristenan tersebut harus menjadi bagian penting dalam kurikulum pendidikan perdamaian.

\section{Kesimpulan}

Pendidikan perdamaian merupakan sebuah proses yang kompleks karena mengandung berbagai tujuan, kemudian bersifat dinamis, progresif, dan transformatif, serta diperoleh dengan upaya sengaja secara intensional untuk mempromosikan pengetahuan, keterampilan, sikap dan nilai-nilai yang diperlukan untuk membawa perubahan perilaku, sehingga terwujudlah kesejahteraan manusia dan lingkungan. Berdasarkan analisis terhadap karya Lincoln dan AmaLee serta berbagai bahan pustaka maupun Alkitab maka ada dua belas nilai perdamaian yang menjadi dasar pendidikan perdamaian. Secara umum nilai-nilai tersebut terbagi dalam tiga bagian umum yaitu membangun perdamaian dari diri sendiri, meminimalkan penyebab konflik, dan membangun jalan perdamaian.

\footnotetext{
${ }^{45}$ Rendra Andi Christianto, "Pendidikan Perdamaian Dalam Keluarga (Peranan Orang Tua Dalam Penerapan Nilai-Nilai Perdamaian Dalam Keluarga Di GKMI Siloam)” (Skripsi, Fakultas Teologi, Universitas Kristen Satya Wacana, 2014), http://repository.uksw.edu/handle/123456789/8889.

${ }^{46}$ Lincoln and AmaLee, Peace Generation: 12 Nilai Dasar Perdamaian, 182-183.
} 
Dalam bagian pertama, pendidikan Kristen untuk perdamaian harus membimbing murid menerima dirinya sendiri dan mengindari prasangka buruk. Dalam nilai pertama, inti pentingnya adalah setiap orang diciptakan dengan beberapa karakteristik baik yang positif maupun negatif, serta yang bisa diubah dan tidak bisa diubah. Bagi pendidikan Kristen, nilai ini perlu diberi penekanan bahwa untuk berdamai dengan orang lain, manusia perlu terlebih dahulu berdamai dengan dirinya sendiri. Untuk berdamai dengan diri sendiri, maka manusia haruslah terlebih dahulu diperdamaikan dengan Allah. Manusia harus berdamai dengan Allah karena adanya dosa yang menyebabkan manusia memiliki "konflik" dengan Allah. Kehadiran Yesus di dunia merupakan jalan pendamaian bagi manusia (II Kor. 5:19; Kol. 1:20; I Yoh. 2:2; 4:10) dan itu berarti bahwa pendidikan Kristen memberi penekanan bawah di dalam Kristus manusia dapat berdamai dengan Allah, baru kemudian berdamai dengan dirinya sendiri dan orang lain. Terkait dengan prasangka, ada penekanan bahwa setiap orang perlu belajar untuk melihat setiap orang sebagai individu, setiap manusia tidak boleh dicap baik atau buruk, pintar atau bodoh, kaya atau miskin hanya berdasarkan kesukuan, agama, dan status sosialnya. Alkitab dalam Yakobus 2:1-13 adalah landasan akan nilai tentang prasangka. Dalam teks Yakobus 2:1-13, setiap orang yang beriman kepada Yesus Kristus, tidak boleh membangun prasangka dengan melihat penampilan orang lain.

Untuk meminimalkan hambatan menuju perdamaian, maka perlu dibangun pengertian dan sikap yang menghargai keragaman etnis, perbedaan agama, perbedaan jenis kelamin, status sosial seperti kaya miskin, dan perbedaan kelompok. Sementara dalam upaya membangun jalan menunju perdamaian, lincoln dan amalee mengemukakan lima jalan dan kelima jalan tersebut dapat digunakan pula dalam pendidikan Kristen untuk perdamaian. Lima jalan perdamaian yang menjadi nilai kedelapan hingga keduabelas nilai perdamaian lincoln dan amalee adalah memahami keragaman, memahami konflik, membangun sikap menolak kekerasan, adanya kerelaan untuk memulai mengakui kesalahan, dan kerelaan untuk memberi maaf.

\section{Referensi}

AmaLee, Irfan. “Sejarah Berdirinya PeaceGen.” Accessed June 15, 2018. http://irfanamalee.wixsite.com/pgproject/about1.

Brownlee, Malcolm. Tugas Manusia Dalam Dunia Milik Tuhan. Jakarta: BPK Gunung Mulia, 2004.

Budiarti, Tirsa. "Model-Model Pendidikan Perdamaian Bagi Anak Dalam Konteks Gereja." Jurnal Jaffray 16, no. 1 (March 18, 2018): 55-76.

Christianto, Rendra Andi. "Pendidikan Perdamaian Dalam Keluarga (Peranan Orang Tua Dalam Penerapan Nilai-Nilai Perdamaian Dalam Keluarga Di GKMI Siloam).” Skripsi, Fakultas Teologi, Universitas Kristen Satya Wacana, 2014. http://repository.uksw.edu/handle/123456789/8889.

Juditha, Christiany, and Christiany Juditha. "Stereotip dan Prasangka dalam Konfl ik Etnis Tionghoa dan Bugis Makassar." Jurnal ILMU KOMUNIKASI 12, no. 1 (June 17, 2015): 87-104. 
Lincoln, E., and I. AmaLee. Pake Otak, Jangan Maen Otot: Tentang Menolak Kekerasan. Bandung: Pelangi Mizan, 2007.

Lincoln, E., and Irfan AmaLee. Konflik Bikin Kamu Makin Dewasa: Tentang Konflik. Bandung: Pelangi Mizan, 2007.

Lincoln, E., and Irfan Amalee. Peace Generation: 12 Nilai Dasar Perdamaian. Bandung: Pelangi Mizan, 2007.

Lincoln, Erik, and I. AmaLee. Nggak Gengsi Ngaku Salah: Tentang Mengaku Kesalahan. Bandung: Pelangi Mizan, 2007.

Lincoln, Erik, and Irfan AmaLee. No Curiga, No Prasangka: Tentang Prasangka. Bandung: Pelangi Mizan, 2007.

Mania, Sitti. "Implementasi Pendidikan Multikultural Dalam Pembelajaran." Lentera Pendidikan : Jurnal Ilmu Tarbiyah dan Keguruan 13, no. 1 (June 22, 2010): 78-91.

Mulia, Musdah. "Melawan Kekerasan Atas Nama Agama." In Teologi Politik. Makassar: Yayasan Oase Intim, 2013.

Nugroho, Oktavianus Heri Prasetyo. "Meretas Damai Di Tengah Keberagaman: Mengembangkan Pendidikan Kristiani Untuk Perdamaian Dalam Perspektif Multikulturalisme." Gema Teologi 38, no. 2 (2014): 143-170.

Rumbi, Frans P. “Tradisi Massuru' dan Pertobatan Dalam Injil Sinoptik." BIA': Jurnal Teologi dan Pendidikan Kristen Kontekstual 1, no. 1 (June 30, 2018): 26-38.

Rumbi, Frans Paillin. "Manajemen Konflik Dalam Gereja Mula-Mula: Tafsir Kisah Para Rasul 2:41-47." Evangelikal: Jurnal Teologi Injili dan Pembinaan Warga Jemaat 3, no. 1 (January 30, 2019): 9-20.

Saputra, Wahyu Nanda Eka. "Pendidikan Kedamaian: Peluang Penerapan Pada Pendidikan Tingkat Dasar Di Indonesia." Jurnal CARE (Children Advisory Research and Education) 3, no. 3 (March 16, 2016): 88-94.

Sidjabat, Binsen S. Mendidik Warga Gereja Melalui Seri Selamat. Jakarta: BPK Gunung Mulia, 2018.

Sidjabat, Binsen Samuel. "Penguatan Guru PAK Untuk Pendidikan Karakter: Melihat Kontribusi Seri Selamat." Evangelikal: Jurnal Teologi Injili dan Pembinaan Warga Jemaat 3, no. 1 (January 30, 2019): 30-48.

Sinaga, Sahat M. "Negeri Pancasila: Panggilan Inklusif Gereja Di Indonesia." In Melaksanakan Amanat Agung Di Abad 21. Ungaran: Sekolah Tinggi Teologi Simpson, 2017.

Suparlan, Parsudi. "Konflik Sosial Dan Alternatif Pemecahannya." Antropologi Indonesia 30, no. 2 (2006): 138-150.

Verkuyl, J. Etika Kristen: Seksuil. Jakarta: BPK Gunung Mulia, 1989.

Vita, Yan. "Penamanan Budaya Damai Via Pendidikan." Dimas: Jurnal Pemikiran Agama untuk Pemberdayaan 14, no. 1 (March 7, 2016): 17-28.

Zainiyati, Husniyatus Salamah. "Pendidikan Multikultural: Upaya Membangun Keberagamaan Inklusif di Sekolah." ISLAMICA: Jurnal Studi Keislaman 1, no. 2 (March 2, 2007): 135-145.

“Cerita Kami." Accessed June 15, 2018. http://www.peace-generation.org/about. 